\title{
Effects of Leadership Styles on Organisational Performance in Ahantaman Rural Bank Limited
}

\author{
Article by Augustine Ngmentomo Beakana \\ Business and Management, Texila American University, Universidad Central de Nicaragua \\ E-mail: abeakana@gmail.com
}

\begin{abstract}
The study was intended to investigate the effects of leadership styles on organizational performance in Ahantaman Rural Bank from 2013 to 2016. The study also sought to investigate any relationships between leadership styles and overall performance of the Bank. The main objective of the study was to investigate what type (s) of leadership style ( $(s)$ led to improved organizational performance in the Bank. The specific objectives of the study were to investigate the relationship between leadership styles and organizational performance and the type of leadership style (s) that lead to improved organizational performance.

The study adopted a total population sampling approach to data collection. Among the leadership styles investigated, transformational leadership style obtained the highest raw score of 350 representing 22 percent of the total population investigated. Transactional, democratic, autocratic and laisez-faire leadership styles followed in that order. Thus, it was found that the most dominant and preferred leadership style in the Bank was transformational leadership style. This leadership style led to improved and consistent performance of the Bank.

The study concluded that there was a direct relationship between leadership styles and performance of the Bank. Assessment of the key performance indicators of the Bank and the consistent improvements in these indicators supported the assertion that there is a direct relationship between organizational performance and leadership styles. It is suggested that the scope of this study should be expanded by future researchers who intend to investigate the same subject. The expansion will lead to generalizability of the findings.
\end{abstract}

Keywords: Leadership style, Organizational performance, performance indicators.

\section{Introduction}

The success of every organisation depends largely on leadership and for that matter the leadership style (s) adopted by the leader. Leadership is a universal feature of human societies and affects the quality of life of citizens in important ways (Brown, 1991; R. Hogan, Curphy, \& Hogan, 1994). It becomes more important in times of crisis and leaderships of companies fail in the execution of their contract with shareholders and stakeholders. Leadership has been defined variously by different writers and scholars in recent times. Leadership has become a buzzword for even the ordinary person who does not have formal training in the social sciences.

Leadership is the ability to inspire confidence and support among the people who are needed to achieve organizational goals (DuBrin, 2012). Another definition most appropriate to this paper and worth mentioning is the one given by the Investopedia. According to the Investopedia, "Leadership is the ability of a company's management to set and achieve challenging goals, take swift and decisive action, outperform the competition, and inspire others to perform well." These definitions suggest that achievement of organizational goals depend on leadership in that organization irrespective of the type and size. Leadership is needed in both private and public organizations as well not for-profit organizations. The success of leadership therefore can be attributed to the type of leadership style (s) the leader demonstrates and more so, the environment.

A lot of organizations have faced serious problems due to bad leadership since time immemorial and even in recent times. More than 30 microfinance institutions in Ghana collapsed in the first quarter of 2013 as a result of their inability to sustain their operations (Ghana Business News, 2013). The collapsed of these microfinance institutions can be attributed to bad leadership. In another development, some five (5) rural banks have faced serious leadership crisis in their operations that have led total overhauling 
of its entire management (Ghana News Agency, 2015). Good leadership could have resolved some of the problems that have crippled these financial institutions and many other organizations around the world.

In view of the foregoing, the investigator is of the view that, good leadership in organizations can lead to organizational performance. It is in view of the problems bad leadership does to organizations that the study intends to investigate the effects of leadership on organizational performance in Ahantaman Rural Bank Limited (the Bank). The Bank had had its own share of leadership crisis and this study will confirm whether or not the leadership style adopted by management level staff was having an effect on the Bank's performance spanning from 2013 to 2016.

\section{The problem statement}

There has been reported cases of leadership failure or management crisis in some organizations in Ghana especially in the microfinance and rural banking sectors of the economy in recent times (Ghana Business News, 2013; Ghana News Agency, 2015). These problems cannot be said to be limited to the boundaries of Ghana alone but a global phenomenon. It cannot also be limited to only one particular industry but across all types of industries as well as business and government establishments.

The study sought to investigate the effects of leadership style on organizational performance in Ahantaman Rural Bank Limited in the last four (4) years, from 2013 to 2016. The study also sought to investigate any relationships between leadership style (s) and overall performance of the Bank.

\section{Research questions}

This study seeks to find empirical answers to the following research questions:

i. What type of leadership styles lead to improved organizational performance in Ahantaman Rural Bank?

ii. What is the relationship between leadership style and organizational performance?

\section{Objectives of the study}

The main objective of the study was to investigate what type of leadership style leads to improved organizational performance in the Bank. More specific objectives were:

i. To investigate the relationship between leadership style (s) and organizational performance, and

ii. To investigate the type of leadership style (s) that lead to improved organizational performance.

Appropriate research instruments were designed to gather data for analysis towards achievement of the above research objectives.

\section{Rationale of the study}

Given the importance of rural banks to the economic and social development of Ghana, there is the need to ensure that all rural banks are sustainable. Any insolvency may adversely affect the investors' capital in particular and the economy in general. One of the factors that may affect the successful operations of rural banks is bad leadership by both the Board and Management. Bad leadership is one of the challenges faced by rural banks in Ghana (Ghana News Agency, 2015). In view of the governance structure of rural banks and the selection process of the Executive Management as well as the Branch Managers, leadership has become quite problematic in some rural banks in Ghana.

The subject area will help the Bank to adopt and incorporate leadership styles that influence optimum organizational performance. The Bank will come to appreciate leadership styles, practices and principles that work best for managing financial institutions. Again, upon the successful completion of this study, the findings can be used for refinement of the leadership style of Management in managing the Bank.

Upon adoption of good leadership styles in the Bank based on the findings, the Bank will increase its profitability and ensure sustainability. It is through sustainability that the Bank can discharge its corporate social responsibility. The study will therefore help society to benefit from the corporate social responsibilities provided by the Bank as a result of the incorporation of suitable and appropriate leadership styles that ensure profitability and sustainability. Generally, the findings of this study will 
serve as a literature and reference material for other researchers, individuals, other institutions and may be shelved in community libraries.

\section{Scope of the study}

The scope of this study covered the major thematic areas of leadership - leadership styles and organizational performance. Specifically, this article analysed the current leadership styles that have worked well in organizations in general.

\section{Literature review}

This presents the relevant theoretical and empirical literature on the effects of leadership style on organizational performance. The first section explores the theoretical underpinning of the study including the meaning of leadership, evolution of leadership and emergence of leadership styles. The rest looked at organizational performance and the relationship between organizational performance and leadership styles. The second section examines empirical literature on the effects of leadership style on organizational performance in some selected industries.

\section{Theoretical review}

\section{Definition of leadership}

Leadership does not have a single definition as it has been defined differently by different writers and scholars. Burns (1978) commented that, "Leadership is one of the most observed and least understood phenomena on earth." This does not imply that there is multiplicity of definitions but it also shows how the various theories of leaderships are applied today. Leadership is defined as the ability to inspire confidence and support among the people who are needed to achieve organizational goals (DuBrin, 2012). Another definition most appropriate to this paper and worth mentioning is the one given by the Investopedia. According to the Investopedia, "Leadership is the ability of a company's management to set and achieve challenging goals, take swift and decisive action, outperform the competition, and inspire others to perform well." The ability of a leader to inspire and motivate followers to achieve organizational goals is very essential for achievement of holistic organizational performance.

\section{Evolution of leadership theories}

Leadership as a role and discipline has evolved over the years. This evolution has come about as a result of the innate nature of humans and their environment to change. It is believed that groups with leaders generally do better than groups without leaders.

Leadership considerations may be the additional benefits the follower gets from following as well as who is the right person to follow in a particular situation. This section seeks to give a general picture of the historical foundations of leadership theory and catalogue the progress that has been made so far.

The historical development of leadership thought include: the personality era, the influence era, the behaviour era, the situation era, the contingency era, the transactional era, the anti-leadership era and the culture era. The rest are: the transformational era, fulfilling prophecy period. These eras have been briefly explained in turn.

The personality era looked at the first formal leadership thoughts which formed the basis of understanding the leadership process. Bowden (1927), equated leadership with personality. This assertion implies that people with strong personalities are likely to become leaders. Even leadership theorists believed that leadership was also based on inheritance (Jennings, 1960). This era also attempted to link personality traits with leadership but later empirical studies did not support this thinking (Jenkins, 1947). Following the above, the personality era is more appropriate and suited to the situational and circumstantial factors that call for leading people.

The next leadership era worth mentioning is the influence era. This era is an improvement on the personality era. This era recognized that leadership is a relationship between individuals and not a characteristic of the solitary leader (Van Seters and Field). By inference, the leader may not be able to achieve great results without the cooperation of followers. The leader, irrespective of the leadership dispensation, will always require the cooperation of followers. In soliciting the cooperation and support 
of followers toward achievement of organizational goals, it is not appropriate to resort to the use of power and authority in order to influence workers.

On the other hand, the behaviour era took an entirely new direction by putting more emphasis on what leaders do than the leader's source of power and personality traits. In this era, leadership was defined as a subset of human behaviour (Hunt and Larson, 1977). This was a major progress in leadership theory not only because it enjoyed strong empirical support (Fleishman and Harris, 1962). The behaviour era gained more prominence at the time because it could easily be implemented by practising managers to make them more effective and efficient. The behaviour era was divided into two namely, the early behaviour period and late behaviour period. The early behaviour period was an extension of the trait era that placed more emphasis on developing behaviour traits.

Furthermore, the situational era made significant progress in promoting leadership theory by considering the factors beyond the leader and subordinate. The social status of the leader and his subordinates as well as the relative position power of the leader and subordinates and the external environment could influence the leader's behaviour (Bass, 1981). Situational factors confronted by the leader go to determine the kinds of traits, behaviours, skills and influence that may cause the leader to be effective or otherwise. The situational era is further divided into the environmental period, the social status period and the socio-technical period. In the environment period, the actions of leaders did not matter but being in the right place at the right time and in the right circumstances could favour a person in becoming a leader (Hook, 1943). In the social status period, group members' expectations were reinforced with the view that individual member's behaviour will remain consistent with their previous behaviours. Here, the leader's and the subordinate's roles are defined by mutually confirmed expectations of the behaviour and interactions they are permitted to contribute to the group (Stogdill, 1959).

Moreover, the contingency era formed a major advancement in the evolution of leadership thought. The contingency era found effective leadership to embrace factors such as personality, behaviour, situation and influence and not one variable. On the other hand, the transactional era disassociated itself from the assertion that leadership resided in the person or situation. The transactional era addressed the influence between the leader and subordinate through the reciprocal influence between the subordinate and the leader.

Besides, the anti-leadership era tested the aforementioned theories that have been explained so far but departed from all the views held by the various theorists. In the anti-leadership era, subordinates did not see the relevance of the leader and thus, the rise of anti-leadership movement among subordinates. Flowing from the foregoing, Miner (1975) suggested that we give up and abandon the concept of leadership altogether.

The culture era saw the creation and sustenance of a strong organizational culture that was strongly advocated for in this era. The focus of leadership here was one of creating a culture that becomes the pivot for increasing organizational performance, effectiveness and efficiency. In the words of Manz and Sims (1987), "if a leader can create a strong culture in an organisation, employees will lead themselves" is worth noting. It is more difficult leading in an organization without a strong organizational culture and vice-versa.

Finally, the transformational era is the most recent and most promising in the evolutionary development of leadership theories. Bass (1985), suggested that leaders must be proactive rather than reactive in their thinking; radical rather than conservative; more innovative and creative; and more open to new ideas. Following the above, leadership is expected to influence their subordinates in a manner that increase the commitment and support from all organizational members including subordinates. Transformational leadership is essential during organizational transition by creating visions of potential opportunities and instilling employee commitment to change (Tichy and Ulrich, 1984). Here, without a passionate articulation of the vision, employee commitment and provision of adequate resources, leadership might not succeed.

There are two periods in this era which include: the Charisma Period and the Self-Fulfilling Prophecy (SFP) Period. The main thrust of the Charisma period is that the leader must be a visionary, able to align the personal goals of organizational members to his vision for the organization and move all along the new direction. In the view of Roberts (1985), the Charisma Period builds on the Culture Era by viewing 
leadership as a process of collective action. Leadership must not only rest on the leader's shoulders but all organizational members must throw their support behind leadership. Unlike the Charisma Period, the SFP Period is based on theory by Field (1989). The SFP can be activated from both the top and lower levels of the organization. Here, transformation can emanate from the subordinate to the leader and vice-versa.

\section{Leadership styles}

Leaders adopt different leadership styles in leading their followers. The style (s) the leader applies depends on a host of factors including the situational factors, personality traits and experience. According to the Wikipedia, "A leadership style is a leader's style of providing direction, implementing plans, and motivating people." Different leaders lead differently but as to which style produces the best results, depends on situational factors and experience of the leader at a particular time. To help determine which leadership style is dominant in Ahantaman Rural Bank and its effect on bank performance, the study adopted five out the six leadership styles opined by Daniel Goleman (2000) in his article "Leadership that Gets Results." The five leadership styles include: Authoritarian style, Democratic style, Laissez-faire style, Transactional style and transformational style. These leadership styles are briefly described in the section that follows.

An Autocratic leader is a task- oriented leader who retains most of the authority for himself or herself and is not generally concerned with group members' attitudes toward decisions (DuBrin, 2012). He does not usually care about the reactions or feedback of subordinates following the implementation of a particular decision. What matters to him is that the decision satisfies his interests and that of the organization. These types of leaders believe in creating a distinct professional relationship with subordinates. These types of leaders hold the theory $\mathrm{X}$ view of leadership and also believe in close supervision of subordinates.

Also, the democratic leadership style is believed to be most recommended one opined by many academics and practitioners in recent times. According to DuBrin (2012), "democratic leaders confer final authority on the group. They function as collectors of opinion and take a vote before making a decision." In democratic leadership style, the leader shares the decision-making process with members of the organization by way of employee involvement and participation. Employee involvement is the process of including employees in the decision-making process whereas, employee participation consists of allowing employees to make inputs into the decision-making process. Here, employees are seen as partners and play a crucial role in managing the organization. Democratic leadership style promotes teamwork and strong group cohesion among members of an organization. This leadership style can bring about increased productivity because it encourages sharing of better ideas which eventually could lead to creative and innovative solutions to organizational problems. Conversely, democratic leadership style can lead to waste of man hours and low productivity in organizations with poor cultural orientations and cultural values. This leadership style may not also be suitable for business enterprises though the most advocated for in the last decades.

Moreover, the laissez-faire leadership style gives all the right and power to decision-making to the staff to perform their duties assigned them. Here, the leader provides all the necessary resources for staff to perform their functions. Employees have the freedom and liberty to take decisions that will inure to the benefit of the organization without unnecessary interference from the leader. The leader only comes in when employees invite the participation of their leader otherwise, the leader's involvement will be resisted by employees. Laissez-faire leadership style works best when: the organizational culture in an organization promotes employee commitment and loyalty, employees are highly skilled and experienced, employees are specialist in their domain of work and when the leader has put in place monitoring mechanisms to track the performance of each employee in the organization. However, this style should not be used if the leader does not have the capacity to monitor the work of his employees.

Besides, the transactional leadership style pays more attention to the motivation and punishment of employees through rewards and sanctions. Here, employees who are considered performers are rewarded appropriately while non-performers are punished accordingly. Under this leadership style, the leader identifies the peculiar needs of employees and provides the motivation to increase staff 
performance. Transactional leaders focus on increasing the efficiency of established routines and procedures.

Finally, a transformational leader is the one who helps organizations and people make positive changes in the way they do things (DuBrin, 2012). This leadership style combines charisma, inspirational leadership, and intellectual stimulation in leading organizational members. By combining charisma, inspirational leadership and intellectual stimulation, this type of leader is able to cause a dramatic change in the way organizations work and achieves significant results. The organizational characteristics and the leader's charisma are key to how transformations take place in organizations. Transformational leaders attempt to overhaul the organizational culture or subculture and to make a difference in people's lives. To bring about the overhaul, transformations take place in one or more of three ways. According to DuBrin, 2012, transformations in organizations take place in the following three ways:

i. The transformational leader raises awareness of the importance and value of certain rewards and how to achieve them.

ii. The transformational leader gets people to look beyond their self-interests for the sake of the work group and the firm.

iii. The transformational leader helps people go beyond a focus on minor satisfactions to a quest for self-fulfilment.

\section{Empirical review of literature}

Neha Gupta (2014) in his study on the same subject in Jammu region concluded that transactional leadership style was more appropriate in inducing performance in Brick Kilns than transformational leadership style and, therefore, recommended transactional leadership style for the Brick Kilns with inbuilt strategies for transition to transformational leadership style as the enterprises developed, grew and matured. This implies that smaller organizations are more likely to adopt transactional leadership style than bigger organizations. This finding is consistent with that of Obiwuru, et al. (2011) who investigated small scale enterprises in Nigeria. They found that while transactional leadership style had significant positive effect on performance, transformational leadership style had positive but insignificant effect on performance. Some other studies carried out by researchers have deviated from this conclusion.

Peris M. Koech and Prof. G.S. Namusonge (2012) in their study of the same topic in state corporations in Kenya found high $(0.518$ to $0.696, \mathrm{P}<.05)$ correlations between the transformationalleadership factors and organizational performance ratings, whereas correlations between the transactional-leadership behaviors and organizational performance were relatively low ( 0.219 to 0.375 , $\mathrm{P}<$.05). By this, Peris M. Koech and Prof. G.S. Namusonge's findings is consistent with the intuition behind leadership styles in small scale enterprises and much larger organizations, as they explained in their conclusion. As organizations grow, leadership dynamics also change in response to organizational demands and vice-versa.

\section{Organizational performance}

Organizational performance is contingent upon both internal and external environmental factors that affect the organization in a positive or negative manner. For a positive performance to take place in an organization, its leadership must continuously monitor, scan and evaluate the business environment. Some of the tools that can be used in conducting environmental analysis include: SWOT analysis and the PESTLE analysis. SWOT is acronym that stands for strengths, weaknesses, opportunities and threats. Strengths and weaknesses are internal to the organization whereas, opportunities and threats are external to the organization. On the other hand, PESTLE is also an acronym and stands for political, economic, sociocultural, technological, legal and environmental factors. These variables directly or indirectly affect the performance of organizations irrespective of their sizes.

Organizational performance does not have just one definition and have been defined differently. Lebans \& Euske in 2006 gave a set of definitions to describe the concept of organizational performance. This article takes a look at three of Lebans \& Euske (2006, p.71) definitions as follows: performance is a set of financial and nonfinancial indicators which offer information on the degree of achievement of 
objectives and results (Lebans \& Euske 2006 after Kaplan \& Norton, 1992); to define the concept of performance is necessary to know its elements characteristic to each area of responsibility; and to report an organization's performance level, it is necessary to be able to quantify the results. According to the Wikipedia, "Organizational performance comprises the actual output or results of an organization as measured against its intended outputs (or goals and objectives)." It is when organizations have achieved their goals and objectives that we can say these organizations have performed well.

\section{Methodology}

In order to achieve the expected objectives for the project, the researcher used questionnaires as a method of investigation and descriptive statistics in data analysis. Conclusions were subsequently drawn based on the findings of the study. A questionnaire is a pre-formulated written set of questions to which respondents record their answers, usually within rather closely defined alternatives (Sekaran, 2003). The use of questionnaires is more appropriate when the researcher knows specifically what is required and how to measure the variables under consideration. Questionnaires may be administered personally, and mailed or emailed to the respondents depending on the rapport created by the researcher.

\section{Sources of data collection}

Data collection was done using both primary and secondary sources. The primary sources of data collection methods included the administration of questionnaires to twenty-eight (28) Management level Staff of the Bank. The secondary sources used in collecting data included ARB's prudential returns and management reports, Apex bank's efficiency monitoring unit's reports, Ghana club 100 report and premier brands Ghana report. Data from these sources helped the researcher in determining the performance status of the bank.

\section{Population and sampling}

The population understudied was management level officers of the Bank. The population was grouped into top management level staff, unit heads and branch managers. The rationale for choosing the entire population for the study was because they were better placed to provide the researcher with answers to the research questionnaires in view of the managerial role they play in the bank. The sampling size was made of 28 management level staff comprising seven (7) top management staff, four (4) unit heads and seventeen (17) branch managers in the Bank.

Total population sampling was used for the study. Total population sampling is a type of purposive sampling technique where you choose to examine the entire population (i.e., the total population) that have a particular set of characteristics (Lund Research Limited, 2012). The unit of interest which was all management level staff shared some common characteristics as they all manage employees at different levels in the Bank. The sampling unit i.e all management level staff also share uncommon characteristics such experience, academic orientation and social orientation.

Additionally, total population sampling is mostly used when the population size is relatively small and when the population shares uncommon characteristics. In total population sampling, researchers choose to study the entire population because the size of the population has the particular set of characteristics that they are interested in. The characteristic shared by the population is also considered to be uncommon because this tends to explain why the population that can be studied is very small. Data was analysed using tabulation, graphs and charts in the presentation and analysis of collected data from the population.

\section{Research limitations}

One of the limitations of this study is that, the findings and recommendations are intended to address the most preferred leadership style in Ahantaman rural bank and its relationship with the performance of the Bank between 2013 and 2016 and may not be replicated in other rural banks because of environmental dynamics. Another significant limitation is that purposive sampling technique is not representative and therefore cannot lead to generalizability of the research findings. 


\section{Results}

This section of the paper presents results of the topic investigated. The study sought to investigate the effects of leadership styles on organizational performance in Ahantaman Rural Bank from 20132016 and ascertain what leadership style was more dominant among all management level staff of the Bank. The study also sought to find a direct relationship between the dominant leadership style in the Bank and its effect on the performance during the period under review. The results of the study based on the analysis of both primary and secondary data analyses suggest there is a positive effect of leadership style on performance of the Bank and are presented in turn.

Concerning the leadership style that is more dominant and the most preferred among management level staff of the Bank, was the transformational leadership style as shown in table 2. Among the leadership styles investigated, transformational leadership style obtained the highest mean score of 350 representing 22 percent of the total population investigated. This finding is not consistent with the results obtained by Obiwuru, et al. (2011) who investigated the effects of leadership style on organizational performance in small scale enterprises in Nigeria. Obiwuru, et al. (2011) found that while transactional leadership style had significant positive effect on performance, transformational leadership style had positive but insignificant effect on performance. On the other hand, Peris M. Koech and Prof. G.S. Namusonge (2012) in their study of the same topic in State Corporations in Kenya, found high correlations between transformational-leadership factors and organizational performance ratings, whereas correlations between the transactional-leadership behaviours and organizational performance were relatively low. The study thus, shows that transformational leadership is deemed suitable for managing government organizations and bigger enterprises.

Transactional leadership style obtained the second highest mean score of 336 representing 21 percent of the total population whereas, democratic leadership style obtained a mean score of 334 also representing 20 percent of the total population studied. Similarly, autocratic and laissez-faire leadership styles obtained a total mean score each of 288 and 284 representing 18 percent and 17 percent respectively.

With regards to finding a direct relationship between leadership style and organizational performance, the study found a direct relationship between transformational leadership style and Bank performance as there was consistent improvement in the performance of the Bank in the period under review. This is also inconsistent with the findings of Obiwuru, et al. (2011) as their findings showed that transactional leadership style had a direct and positive relationship with organizational performance in small scale enterprises. This result is however, consistent with Peris M. Koech and Prof. G.S. Namusonge (2012) finding on the same topic with emphasis on State Corporations. Table 3 of this study suggests that the Bank has been consistent in improving almost all of its key performance indicators (KPIs) from 2013-2016 financial years. It can be seen from table 3 and figures 2-7 and 9-11 that, the years 2015 and 2016 were the best performing years in the history of the Bank which can be linked with the leadership style adopted by management level staff. Apart from figure 8 (cost income ratio), there were remarkable improvements in all the key performance indicators of the Bank.

\section{Discussion}

Both qualitative and quantitative methods were employed to analyse the data. In validating the accuracy of the data gathered from the various sources, descriptive statistics were generated to present the most preferred leadership style in Ahantaman Rural Bank. Primary data was collected from the population while secondary data was generated from key performance indicators from the year 2013 to 2016.

Though the study found transformational leadership style to be more dominant and the most preferred leadership style among the population studied in table 2, it can be seen that transactional leadership style comes closely after the transformational leadership style. This closeness of results between the transformational and transactional styles of leadership can be explained by the merging of results from 17 operational level managers and 11 top and middle level managers. The question that one may ask is, can the management of an organization adopt more than one leadership style? Your guess is as right as mine. Organizations can adopt more than one leadership style because leadership is situational and circumstantial. The situational factors prevailing at a particular point in time may dictate the leadership 
style that produces optimum results. Management of the Bank should understand that management style alone contributes about 30 percent to the bottom line (profit) of every business enterprise (Goleman, 2000). For leadership style to be effective and achieve the intended results, it should be based on the situational factors.

The Bank failed to achieve the benchmark for cost income ratio which is fixed at 70 percent as shown in figure 8. Though the Bank missed this benchmark consistently during the period under review, it is also indicative that the Bank improved upon the cost income ratio during this same period. One thing that can probably explain this phenomenon is that the Bank was able to increase its expenditure more than its income in the same period. Maybe increasing its revenue generating capacity can see a smaller deviation from the benchmark.

Furthermore, the study found a direct relationship between bank performance and leadership style during the period under review. The researcher has come to this conclusion as the Bank witnessed remarkable improvements almost all of its KPIs. The few areas such as cost income ratio though were behind target also saw much better improvements compared with the period before the study.

\section{Conclusion}

Following the presentation of the results and the discussion thereon, the investigator has come to some conclusions. The conclusions drawn in this study are based on the results that emanated from analysis of the data collected from both primary and secondary sources. These conclusions are discussed in turn.

One conclusion that can be drawn from the findings is that the most preferred and dominant leadership style in Ahantaman Rural Bank is transformational leadership style. A transformational leader is the one who helps organizations and people make positive changes in the way they do things (DuBrin, 2012). This leadership style combines charisma, inspirational leadership, and intellectual stimulation in leading organizational members. By combining charisma, inspirational leadership and intellectual stimulation, this type of leader is able to cause a dramatic change in the way organizations work and achieves significant results. In my view, the Bank has made tremendous strides in its key performance indicators because it adopted a transformational leadership style which is in alignment with modern management trends. This finding is in consonance with

The study also concludes that there is a direct relationship between leadership style and organizational performance. Assessment of the key performance indicators of the Bank and the consistent improvements in these indicators support the assertion that there is a direct relationship between organizational performance and leadership style. Though there exist a strong relationship between the banks's performance and transformational leadership style, there also exist some relationship between performance of the Bank and other leadership styles.

Finally, it is suggested that the scope of this study should be expanded by future researchers who intend to investigate the same subject. The expansion of the scope of this topic can subsequently lead to generalizability and application in other organizations, especially in financial institutions.

\section{Figures and tables}

Table 1. Cross- tabulation of respondents

\begin{tabular}{|l|l|l|l|}
\hline Type of Respondent & $\begin{array}{l}\text { Number of } \\
\text { Respondents }\end{array}$ & $\begin{array}{l}\text { Number Who Did Not } \\
\text { Respond }\end{array}$ & Total \\
\hline Top Management & 6 & 1 & 7 \\
\hline $\begin{array}{l}\text { Branch } \\
\text { Managers/Supervisors }\end{array}$ & 13 & 4 & 17 \\
\hline Unit Heads & 4 & 0 & 4 \\
\hline Total & 23 & 5 & 28 \\
\hline
\end{tabular}

Source: Field Survey, 2017 
DOI: $10.21522 /$ TIJMG.2015.03.02.Art013

ISSN: $2520-310 \mathrm{X}$

Table 2. Scores of leadership styles

\begin{tabular}{|l|l|l|l|}
\hline $\begin{array}{l}\text { Type of Leadership } \\
\text { Style }\end{array}$ & Mean Score & Percentage & Ranking \\
\hline Autocratic & 288 & 18 & $4^{\text {th }}$ \\
\hline Democratic & 334 & 20 & $3^{\text {rd }}$ \\
\hline Laissez-faire & 284 & 17 & $5^{\text {th }}$ \\
\hline Transactional & 336 & 21 & $2^{\text {nd }}$ \\
\hline Transformational & 350 & 22 & $1^{\text {st }}$ \\
\hline
\end{tabular}

Source: Field Survey, 2017

Table 3. Key performance indicators (KPIs) for measurement of ahantaman rural bank's performance

\begin{tabular}{|c|c|c|c|c|}
\hline KPI & Year & Achievement & $\begin{array}{l}\text { Mean } \\
\text { Achievement }\end{array}$ & $\begin{array}{l}\text { Industry } \\
\text { Benchmark }\end{array}$ \\
\hline $\begin{array}{l}\text { Non-Performing Loan } \\
\text { Ratio }\end{array}$ & $\begin{array}{l}2013 \\
2014 \\
2015 \\
2016 \\
\end{array}$ & $\begin{array}{l}10.9 \\
13.6 \\
1.5 \\
1.3\end{array}$ & 6.83 & $5 \%$ \\
\hline Past Due Ratio & $\begin{array}{l}2013 \\
2014 \\
2015 \\
2016\end{array}$ & $\begin{array}{l}16.8 \\
14.1 \\
2.2 \\
1.7 \\
\end{array}$ & 8.7 & $20 \%$ \\
\hline $\begin{array}{l}\text { Earning Assets to Total } \\
\text { Assets Ratio }\end{array}$ & $\begin{array}{l}2013 \\
2014 \\
2015 \\
2016 \\
\end{array}$ & $\begin{array}{l}66.9 \\
74.1 \\
77.2 \\
75.0 \\
\end{array}$ & 73.3 & $70 \%$ \\
\hline $\begin{array}{l}\text { Liquid Assets To Total } \\
\text { Assets Ratio }\end{array}$ & $\begin{array}{l}2013 \\
2014 \\
2015 \\
2016\end{array}$ & $\begin{array}{l}35.5 \\
41.8 \\
47.1 \\
47.0\end{array}$ & 42.85 & $40 \%$ \\
\hline Return On Assets & $\begin{array}{l}2013 \\
2014 \\
2015 \\
2016 \\
\end{array}$ & $\begin{array}{c}3.0 \\
0.8 \\
6.0 \\
5.8 \\
\end{array}$ & 3.9 & $5 \%$ \\
\hline Return On Equity & $\begin{array}{l}2013 \\
2014 \\
2015 \\
2016 \\
\end{array}$ & \begin{tabular}{l|}
35.3 \\
7.9 \\
46.6 \\
37.6 \\
\end{tabular} & 31.85 & $30 \%$ \\
\hline Cost to Income Ratio & $\begin{array}{l}2013 \\
2014 \\
2015 \\
2016\end{array}$ & $\begin{array}{l}83.3 \\
85.6 \\
75.4 \\
78.7\end{array}$ & 80.75 & $70 \%$ \\
\hline Deposit Growth & $\begin{array}{l}2013 \\
2014 \\
2015 \\
2016 \\
\end{array}$ & $\begin{array}{l}31,916,113 \\
37,832,523 \\
41,732,828 \\
54,145,626 \\
\end{array}$ & $41,406.772 .50$ & \\
\hline Profit & $\begin{array}{l}2013 \\
2014 \\
2015 \\
2016\end{array}$ & $\begin{array}{l}1,291,485 \\
220,035 \\
2,943,598 \\
4,027,704\end{array}$ & $2,120,705.50$ & \\
\hline Advances & $\begin{array}{l}2013 \\
2014 \\
\end{array}$ & $\begin{array}{l}17,030,622 \\
20,882,401 \\
\end{array}$ & $21,964,375.75$ & \\
\hline
\end{tabular}




\begin{tabular}{|l|l|l|l|l|}
\hline & 2015 & $21,214,378$ & & \\
& 2016 & $28,730,102$ & & \\
\hline
\end{tabular}

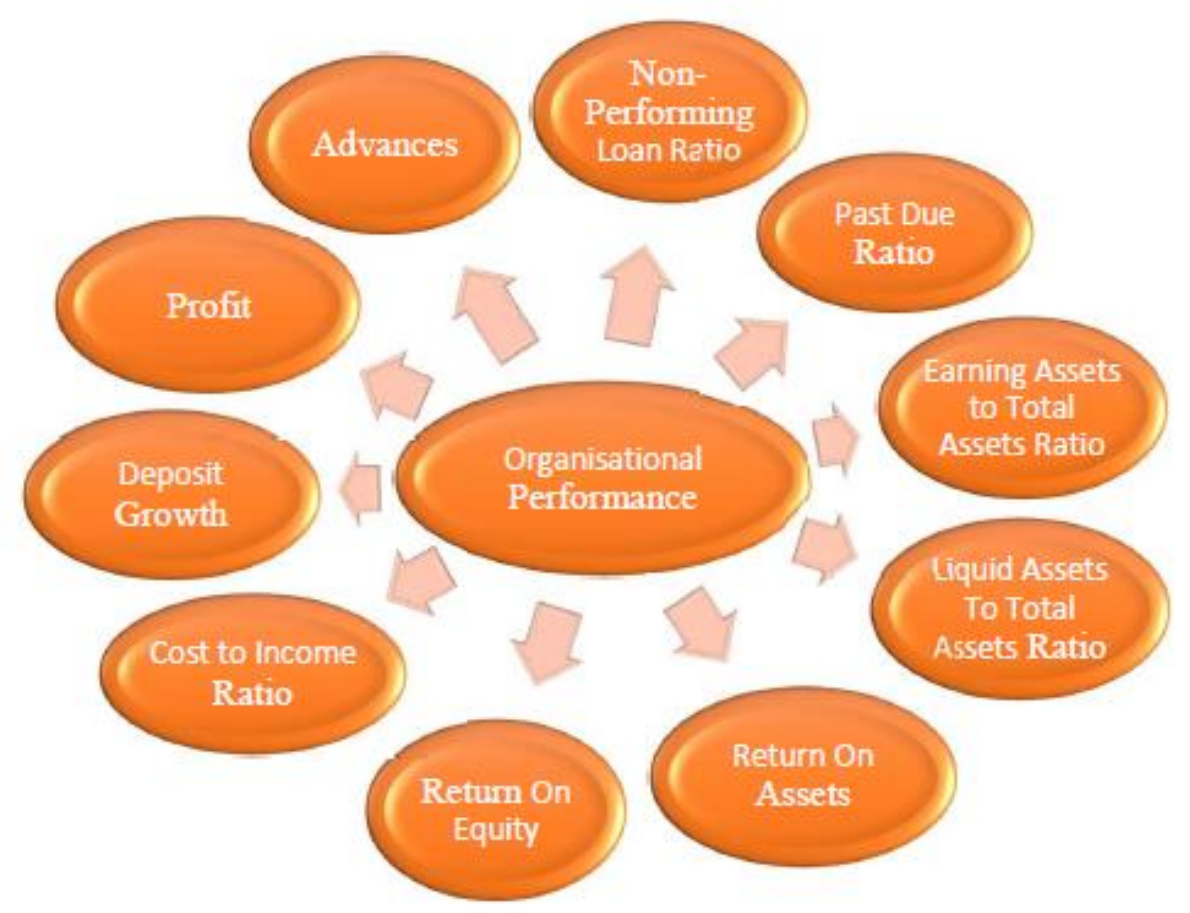

Figure 1. Key performance indicators

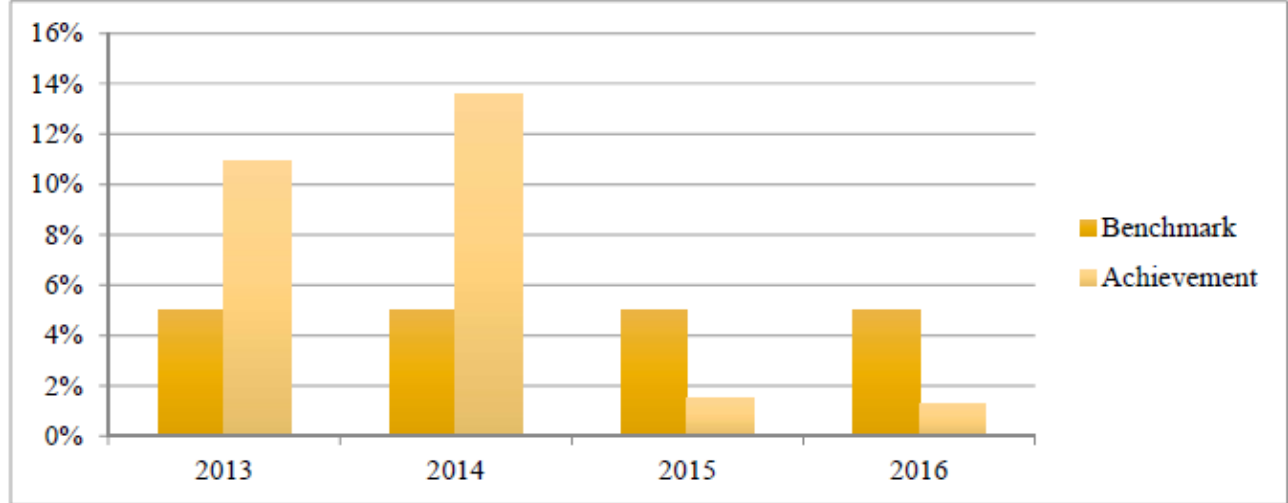

Figure 2. Non-performing loans 
DOI: 10.21522/TIJMG.2015.03.02.Art013

ISSN: $2520-310 \mathrm{X}$

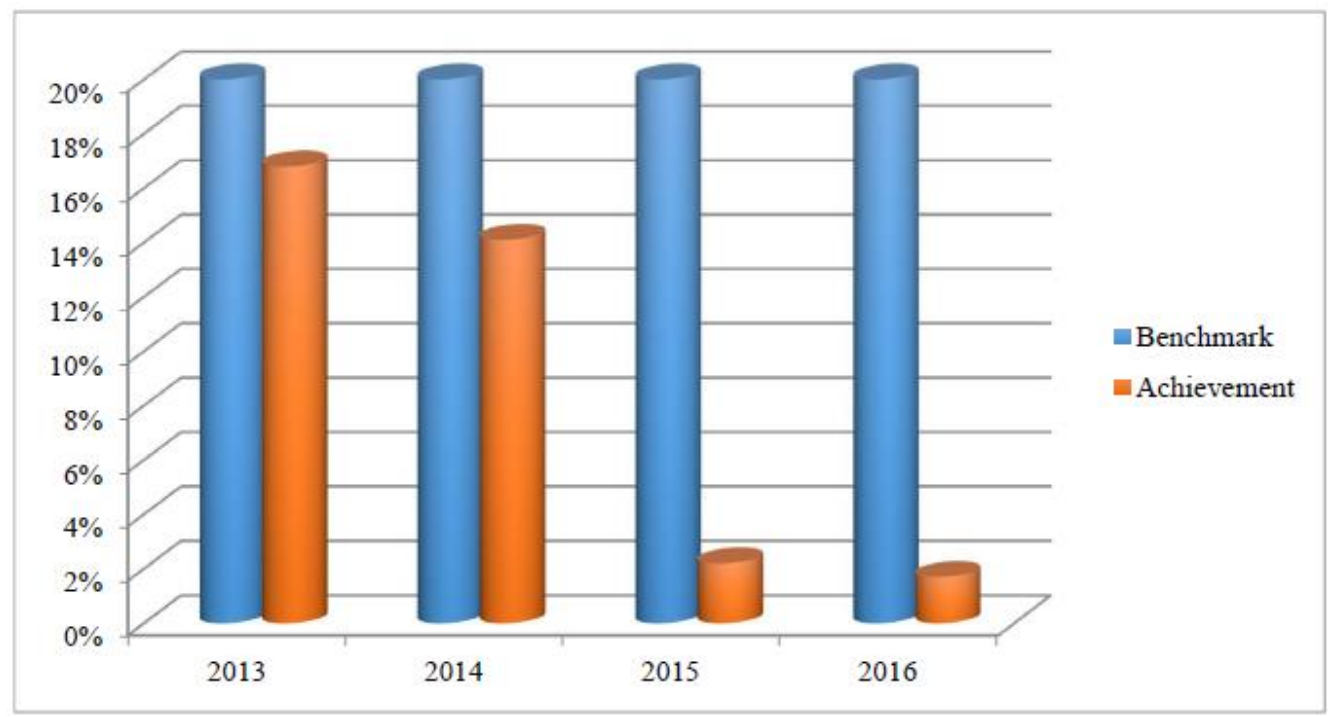

Figure 3. Past due ratio

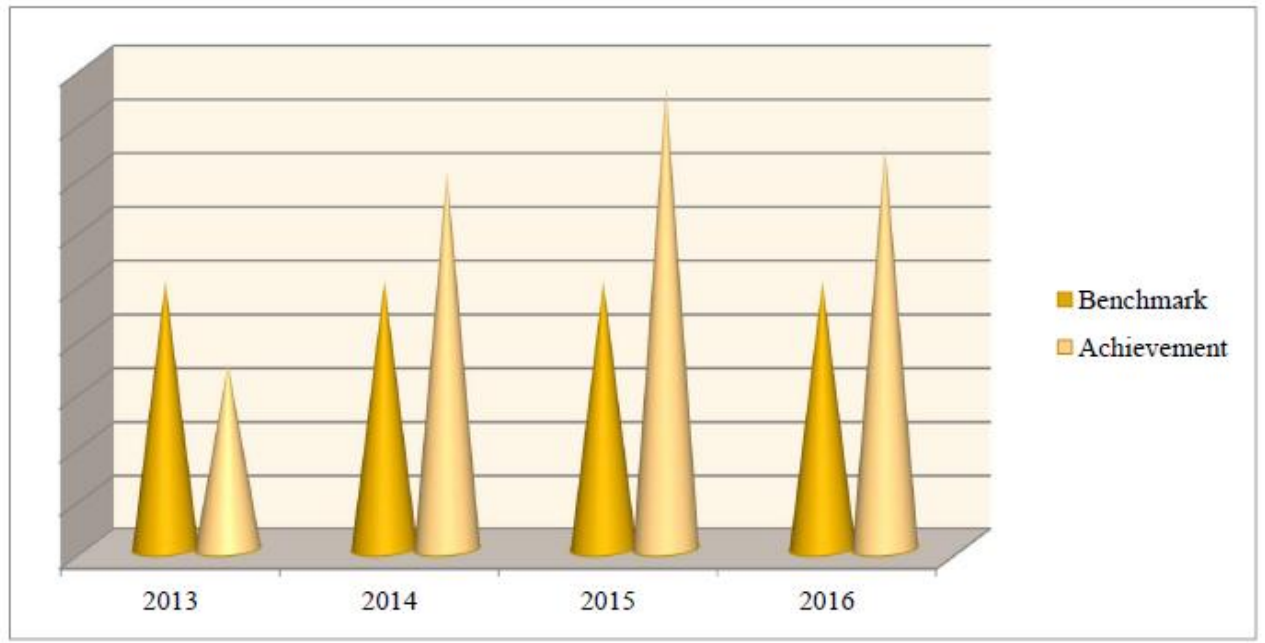

Figure 4. Earning assets to total assets ratio

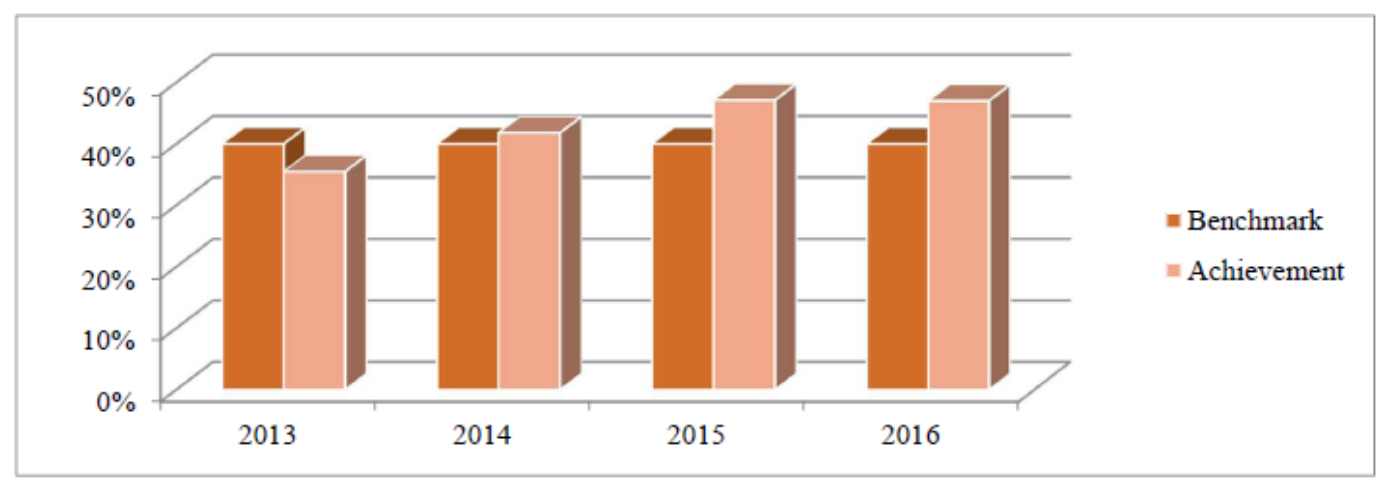

Figure 5. Liquid assets to total assets 


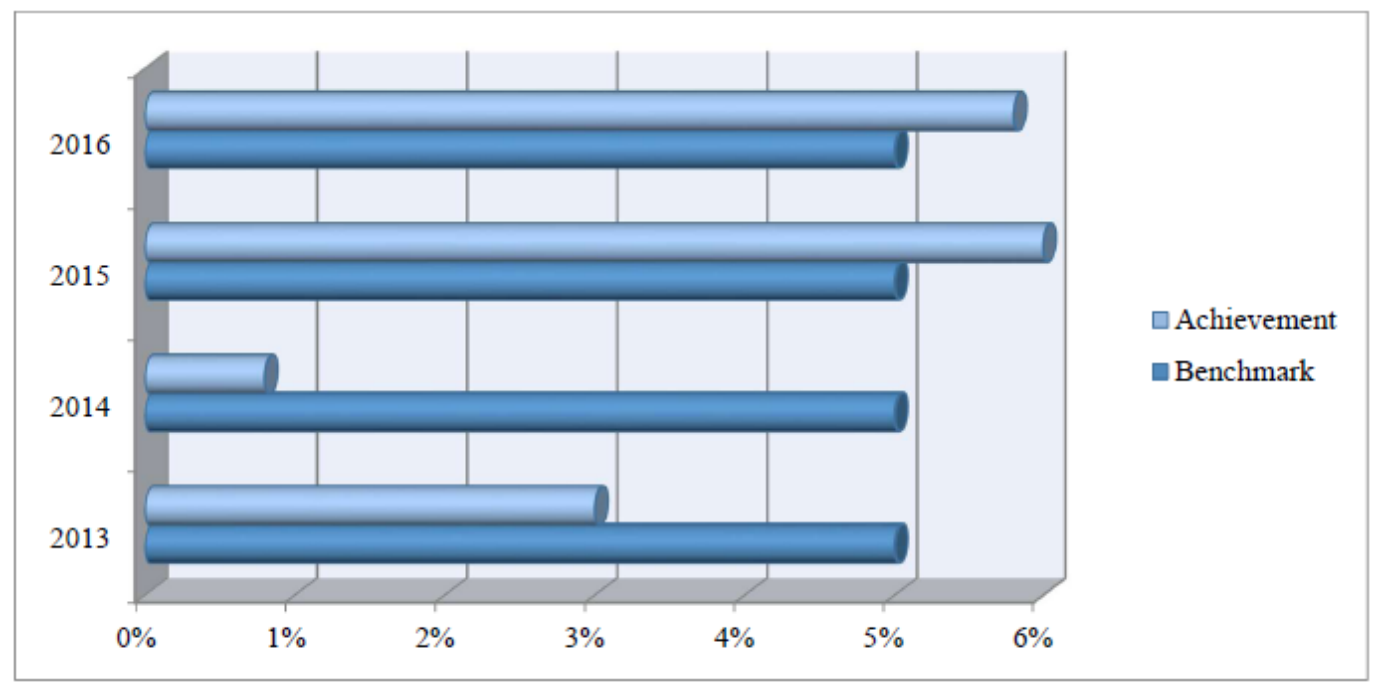

Figure 6. Return on assets

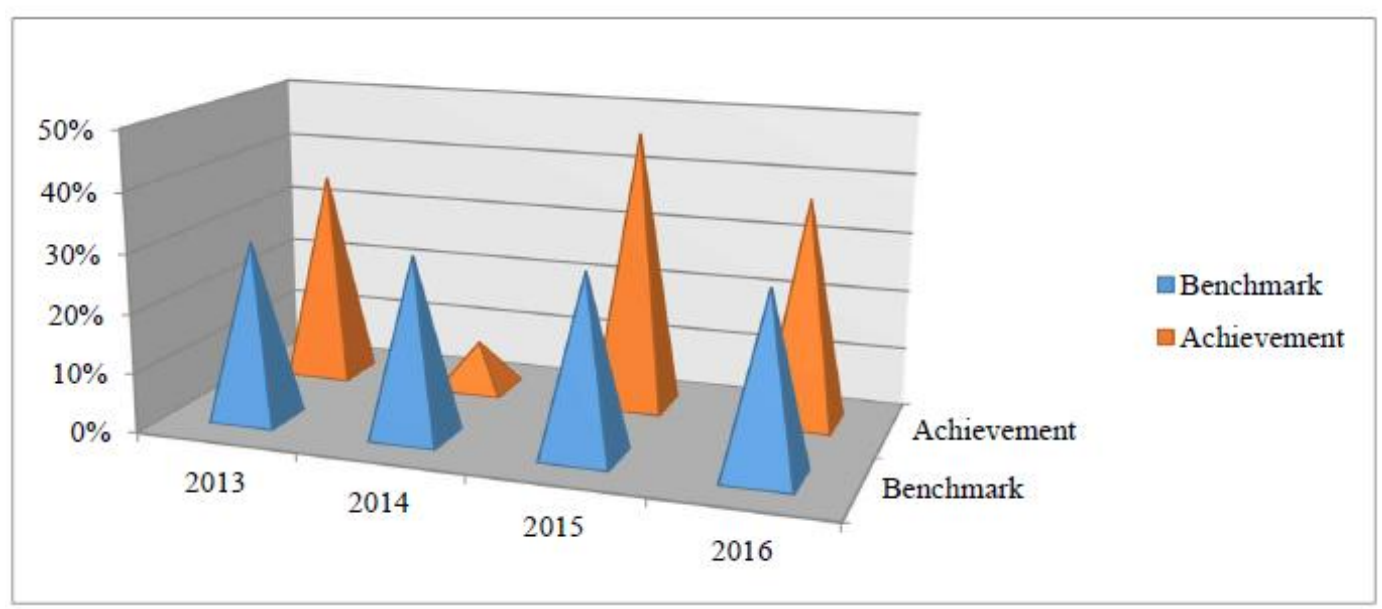

Figure 7. Return on equity

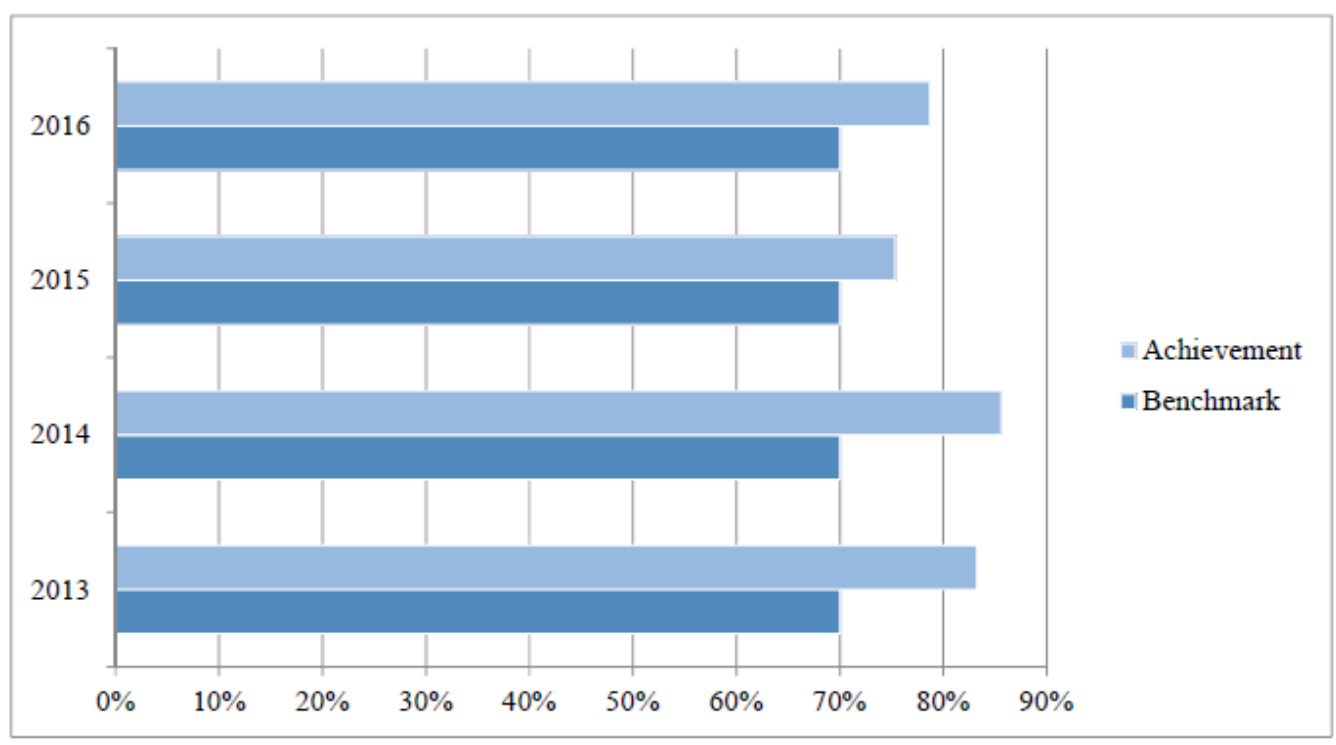

Figure 8. Cost income ratio 
DOI: $10.21522 /$ TIJMG.2015.03.02.Art013

ISSN: $2520-310 \mathrm{X}$

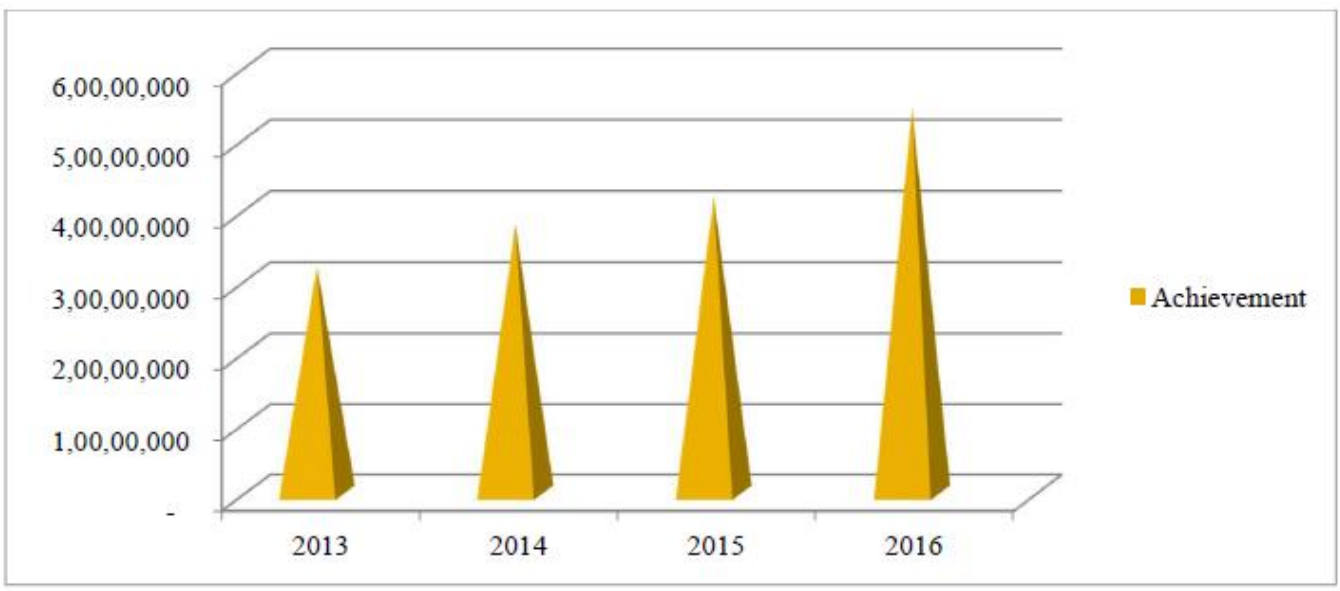

Figure 9.Deposit growth

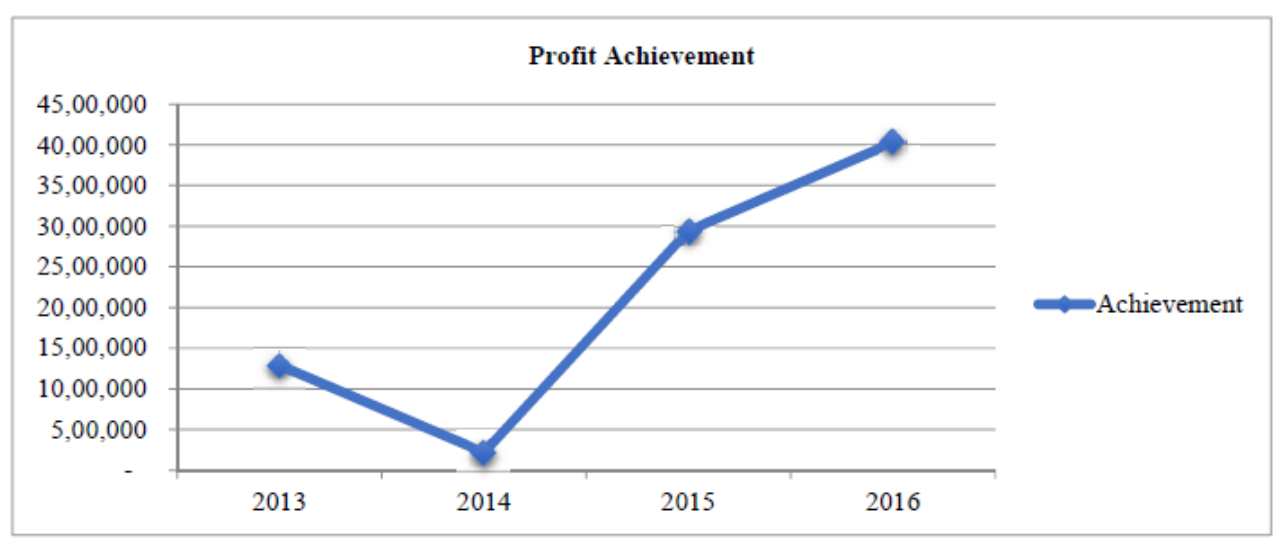

Figure 10. Profit

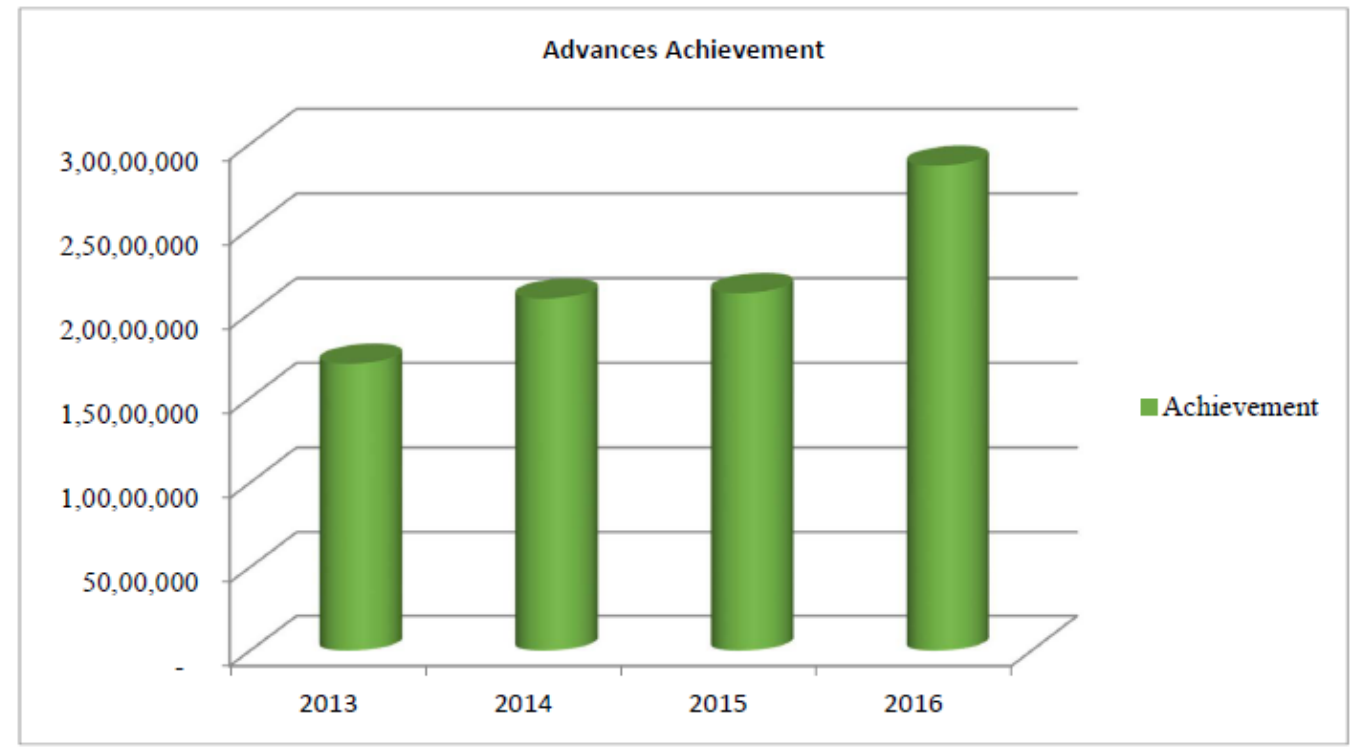

Figure 11: Advances portfolio

\section{Acknowledgement}

My first gratitude goes the Almighty God who has given me life and strength to carry out this study successfully. To attempt to claim originality in any form will amount to academic dishonesty. I owe much to distinguish pioneers in the field of management and other relevant disciplines whose texts I 
have to consult in one way or the other to make this study a reality. I cannot in any way omit the credits where they belong.

In particular, I owe all the faculty members and student co-ordinators a huge debt of gratitude for his invaluable support in the area of guidance. I wish to acknowledge Mr. Daniel Annor for his support to me during the period of carrying out this study.

I wish to also thank the CEO of Ahantaman Rural Bank for accepting to use the Bank as a case study.

\section{References}

[1].Bass, B.M. (Ed.) (1981), Stogdill's Handbook of Leadership: A Survey of Theory and Research (revised and expanded version), The Free Press, New York.

[2].Bass, B. M. (1985). Leadership and Performance beyond Expectations. New York, Free Press.

[3].Bowden, A.O. (1972), "A Study on the Personality of Student Leadership in the United State," Journal of Abnormal Social Psychology, Vol. 21, pp. 149-60.

[4].Brown, D. (1991). Human universals. Boston, MA: McGraw-Hill.

[5].Burns, J. M. (1978). Leadership. New York: Harper \& Row

[6].Dienesh, R.M. and Liden, R.C. (1986), "Leader-member Exchange Model of Leadership; A Critique and Further Development," Academy of Management Review, Vol. II, pp. 618-34.

[7].DuBrin, J.A. (2012). Essentials of Management, $9^{\text {th }}$ Edition, South-Western, USA.

[8].Evans, M.G. (1970), "The Effects of Supervisory Behavior on the Path-goal Relationship", Organizational Behavior and Human Performance, Vol. 5, pp. 277-98.

[9].Fiedler, F.E. (1964), “A Contingency Model of Leadership Effectiveness”, in Berkowitz, L. (Ed.), Advances in Experimental Social Psychology, Academic Press, New York.

[10]. Fiedler, F.E. (1967), A Theory of Leadership Effectiveness, McGraw-Hill, New York.

[11]. Field, R.H.G (1989), "The Self-fulfilling Prophecy Leader: Achieving the Metharme Effect", Journal of Management Studies, Vol. 26 pp. 151-75.

[12]. Fleishman, E.A. and Harris, E.F. (1962), "Patterns of Leadership Behavior Related to Employee Grievances and Turnover", Personnel Psychology, Vol. 15, pp. 43-56.

[13]. French, J.R.P. (1956), “A Formal Theory of Social Power”, Psychological Review, Vol. 63, pp. 181-94.

[14]. Goleman Daniel (2000). Leadership That Gets Results. Harvard Business Review.

[15]. Griffin, R.W., Skivington, K.D. and Moorhead, G. (1987), "Symbolic and International Perspectives on the Leadership: An Integrative Framework", Human Relations, Vol. 40, pp. 199-218.

[16]. Hogan, R., Curphy, G. J., \& Hogan, J. (1994). What we know about leadership. American Psychologist, 49, 493-504.

[17]. Hook, S. (1943), The Hero in History, John Day, New York.

[18]. House, R.J. (1971), “A Path-goal Theory of Leader Effectiveness”, Administrative Science Quarterly, Vol. 16, pp. 321-38.

[19]. Hunt, J.G. and Larson, L.L. (Eds.) (1977), Leadership: The Cutting Edge, Southern Illinois University Press, Carbondale, Illinois.

[20]. Jenkins, W.O. (1947), "A Review of Leadership Studies With Particular Relevance to Military Problems", Psychological Bulletin, Vol. 44, pp. 54-79.

[21]. Jennings, E.E. (1960), An Anatomy of Leadership: Princes, Heroes and Supermen, Harper, New York.

[22]. Kaplan, R.S., Norton, D.P. (1993), "Putting the Balanced Scorecard to Work", Harvard Business Review, September-October, pp. 134-147

[23]. Kerr, S. and Jermier, J.M. (1978), "Substitutes for Leadership: Their Meaning and Measurement", Organizational Behavior and Human Performance, Vol. 18, pp. 329-45.

[24]. Lebans, M., Euske, K. (2006), "A conceptual and operational delineation of performance", Business Performance Measurement, Cambridge University Press

[25]. Neha Gupta (2014). Effects of Leadership Style on Organizational Performance: A Study of Selected Brick Klins in Jammu Region. International Conference on Management and Information Systems.

[26]. Obiwuru, T.C, Okwu, A.T, Akpa, V.O and Nwankwere, I.A (2011). Effects of Leadership Style on Organizational Performance: A Survey of Selected Small Scale Enterprises in Ikosi-Ketu Council Development Area of Lagos State in Nigeria. Australian Journal of Business and Business and Management Research, Vol.1, No.7. 
DOI: $10.21522 /$ TIJMG.2015.03.02.Art013

ISSN: $2520-310 \mathrm{X}$

[27]. Peris M. K. and Namusonge, G.S (2012). Effects of Leadership Styles on Organizational Performance at State Corporations in Kenya. International Journal of Business and Commerce, Vol. 2, No.1.

[28]. Sekaran, U. (2003). Research Methods for Business, $4^{\text {th }}$ Edition, John Wiley \& Sons, Inc.

[29]. Vroom, V.H. and Yetton, P.W. (1973), Leadership and Decision-making, University of Pittsburgh Press, Pittsburgh, Pennsylvania.

[30]. http://www.investopedia.com/terms/s/servant-leadership.asp -assessed on 18/02/2017

[31]. https://www.ghanabusinessnews.com/2013/08/19/30-microfinance-institutions-collapse-and-clients-losemoney/assessed on 18/02/2017

[32]. http://www.ghananewsagency.org/economics/five-rural-banks-face-liquidity-challenges--94489-assessed on $18 / 02 / 2017$

[33]. https://en.wikipedia.org/wiki/Evolutionary_leadership_theory

[34]. https://en.wikipedia.org/wiki/Organizational_performance

[35]. https://www.gipcghana.com

[36]. https://www.arbapexbank.com

[37]. https://www.premierbrandsghana.com

[38]. https://www.researchgate.net/publication/235298299_The_Evolution_of_Leadership_Theory 